\title{
Extension Plant Pathology: Strengthening Resources to Continue Serving the Public Interest
}

\author{
K. L. Everts, L. Osborne, A. J. Gevens, S. J. Vasquez, B. K. Gugino, K. Ivors, and C. Harmon
}

First author: University of Maryland, Lower Eastern Shore Research and Education Center, Salisbury 21801, and University of Delaware, Georgetown 19947; second author: Pioneer Hi-Bred Int'l-Northern Business Unit, Brookings, SD 57006; third author: Department of Plant Pathology, University of Wisconsin, Madison 53706; fourth author: University of California Cooperative Extension-Fresno County 1720 South Maple Avenue, Fresno 93702; fifth author: Department of Plant Pathology, The Pennsylvania State University, University Park 16802; sixth author: Mountain Hort. Crops Research and Extension Center, North Carolina State University, Mills River 28759; and seventh author: Department of Plant Pathology, University of Florida, Gainesville 32611.

Accepted for publication 15 March 2012.

\begin{abstract}
Everts, K. L., Osborne, L., Gevens, A. J., Vasquez, S. J., Gugino, B. K., Ivors, K., and Harmon, C. 2012. Extension plant pathology: Strengthening resources to continue serving the public interest. Phytopathology 102:652-655.

Extension plant pathologists deliver science-based information that protects the economic value of agricultural and horticultural crops in the United States by educating growers and the general public about plant diseases. Extension plant pathologists diagnose plant diseases and disorders, provide advice, and conduct applied research on local and regional plant disease problems. During the last century, extension plant pathology programs have adjusted to demographic shifts in the U.S. population and to changes in program funding. Extension programs are now more collaborative and more specialized in response to a highly

also reduced funding and shifted the source of funding of extension plant pathologists from formula funds towards specialized competitive grants. These competitive grants often favor national over local and regional plant disease issues and typically require a long lead time to secure funding. These changes coupled with a reduction in personnel pose a threat to extension plant pathology programs. Increasing demand for high-quality, unbiased information and the continued reduction in local, state, and federal funds is unsustainable and, if not abated, will lead to a delay in response to emerging diseases, reduce crop yields, increase economic losses, and place U.S. agriculture at a global competitive disadvantage. In this letter, we outline four recommendations to strengthen the role and resources of extension plant pathologists as they guide our nation's food, feed, fuel, fiber, and ornamental producers into an era of increasing technological complexity and global competitiveness.
\end{abstract} educated clientele. Changes in federal and state budgets and policies have
Extension plant pathologists are located throughout the United States to provide research-based information on plant diseases as part of the nationwide Cooperative Extension Service. They are land grant university diagnosticians, faculty, regional specialists, and specialized farm advisors, all with advanced training in plant pathology. They serve as a resource to county extension agents and the agricultural and horticultural industries. They have a unique and critical role in the forecasting, detection, diagnosis, and management of plant diseases on crops used for food, feed, fuel, fiber, and as ornamentals. Successful efforts at reducing plant diseases increase the profitability and provide sustainability to agricultural enterprises. To illustrate the diverse roles of extension plant pathologists and their impact, we provide three case scenarios.

In spring 2009, wheat farmers in the southern United States observed high levels of scab (caused by Fusarium graminearum (Schwein.) Petch and other Fusarium spp.) (4). F. graminearum, which produces several mycotoxins, also causes Gibberella ear rot in corn. Subsequent cool wet conditions in adjacent Midwestern states resulted in delays in corn growth and high levels of corn ear mold. There was concern that the corn crop was contaminated with the mycotoxins deoxynivalenol and zearalenone due to high $F$. graminearum inoculum levels from the infected wheat crop $(13,14)$. Elevators throughout the upper Midwest

Corresponding author: K. L. Everts; E-mail address: keverts@umd.edu

http://dx.doi.org/10.1094/PHYTO-09-11-0251

(c) 2012 The American Phytopathological Society severely discounted the price for grain. Extension plant pathologists in Iowa, Nebraska, South Dakota, Minnesota, and other states began educating producers and grain buyers on identification of specific corn ear molds. Training focused on differentiating ear rots caused by toxigenic species from ear rots caused by nontoxigenic species such as Diplodia maydis (Berk.) Sacc. or Penicillium spp. For example, extension personnel in South Dakota and other states rapidly increased mycotoxin testing in their laboratories to generate and publicize data about the overall quality of the corn crop. This research-based unbiased information demonstrated that the corn crop was primarily affected by nontoxigenic pathogens and allayed fears (19). An increase of $\$ 0.50$ per bushel for corn in the Chicago Board of Trade (CBOT) price occurred at a time of year when CBOT prices are typically falling. Conservative estimates of the value of this extension effort to South Dakota were $\$ 20$ to $\$ 40$ million, and much larger economic benefit occurred throughout the region (L. Osborne, personal communication).

Extension plant pathologists were also battling late blight (caused by Phytophthora infestans (Mont.) de Bary) on tomatoes and potatoes throughout the eastern and midwestern United States in $2009(5,12)$. They disseminated timely research-based information on management geared towards conventional and organic farmers, as well as homeowners. Economic damage from the outbreak was significant in 2009 and lasted for several years. In Wisconsin, for example, late blight prevention in one potato seed producing county alone cost an additional $\$ 1$ million in fungicides in 2010, with the cost of fuel and labor further escalating this economic burden (A. J. Gevens, personal communication). 
Growers relied on extension information on late blight management to reduce costs and improve yields. This information included early alerts of outbreaks, accurate diagnosis of disease, information on fungicide application timing, and education to eliminate the use of ineffective fungicides $(11,17)$.

Extension plant pathologists in California also were working closely with grape growers in 2009 to reduce losses from powdery mildew due to fungicide resistance in Erysiphe necator (schw.) Burr. Applied research was focused on powdery mildew biology, and grower training focused on better use strategies for new fungicides (8). Extension plant pathologists train California growers annually, which improves their profits through the selection and use of proper fungicides, incorporation of multiple classes of fungicides within a season, and application of fungicides at optimal timing. Severe outbreaks of powdery mildew still occur but are strongly correlated with conducive weather, susceptible cultivars, and cultural practices and not with a breakdown of fungicide efficacy.

The rapid response to these three plant disease outbreaks, and numerous others that occurred across the United States, happened because extension plant pathologists were active in every state, conducting adaptive research, and engaging with growers to develop effective management programs. However, reductions in extension-based funding and in extension plant pathology personnel have placed these critical outreach activities in jeopardy. This letter outlines the current challenges to extension plant pathology and presents four recommendations necessary to strengthen extension plant pathology.

\section{BACKGROUND}

Extension plant pathology has changed dramatically since extension was formalized with the passage of the Smith-Lever Act in 1914 (16). Early outreach, typical of extension plant pathology, has been described as "a one-way process in which the university transfers its expertise to key constituents" (18). Arguably, early extension plant pathology interactions were not always one-way, as plant pathologists worked with growers to adapt new procedures to their individual operations. However, extension-grower partnerships have increased in the century since the inception of extension. An increasingly educated clientele ( $7 \%$ of Americans held a high school degree in 1900 compared with more than $80 \%$ today) and multiple venues for accessing information have changed extension plant pathology $(2,20)$. New procedures and practices result from dialogue between farmers and extension plant pathologists and new technologies are frequently demonstrated and adapted through collaborative on-farm trials.

Another change over the last 100 years is that the network that delivers plant pathology information is now more diverse. Some growers receive information from nonprofit organizations, private industry, and paid consultants, all of whom rely on diagnostic services and adaptive research conducted by extension plant pathologists. Few of these nonprofits, industry groups, or consultants conduct their own research. Some exceptions are the nonprofit Rodale Institute and the agricultural chemical industry. However, most of these sources of information are limited in scope because they focus on a narrow range of issues or approaches. For example, not-for-profit organic organizations will not educate growers about the use of a genetically modified disease-resistant cultivar, even if the use of the cultivar is economically and environmentally beneficial. Consulting services are often provided to growers through agrichemical suppliers who sell specific products. Advice from these services, if researchbased, relies heavily on extension plant pathology first for diagnosis of disease, and then for information on product efficacy. Even private consultants who have advanced plant pathology training and are not affiliated with an agrichemical dealer rely on extension plant pathology for testing of new technologies, weather based forecasting, pathogen monitoring, and diagnostic services. Extension plant pathologists also assist agricultural producers in compliance with federal and state safety and environmental laws that impact disease management options. For example, the Food Quality Protection Act of 1996 changed the way that the Environmental Protection Agency (EPA) regulates pesticides and led directly or indirectly to the cancellation or loss of some crop registrations $(1,15)$. Extension plant pathologists work with agricultural producers to find alternative management practices to mitigate these losses. They also collect and document technical information necessary to register pesticides under Section 18 and 24(c) provisions of the Federal Insecticide, Fungicide, and Rodenticide Act.

As noted previously, the education level of extension clientele has increased, raising the technical level of information needed by the public. Extension plant pathologists now spend significant effort in providing in-service training to county-based faculty (extension agents) and private agricultural service providers, such as consultants and agricultural chemical dealers.

\section{THE SITUATION}

There has been an erosion of resources for extension due to the current economic downturn and the demographic shifts that have reduced the visibility of extension (6). Even before the recent recession, the amount of federal formula funds for agricultural research was in decline. (Formula funds are allocated to states based on a formula that includes their share of the United States' rural and farm populations.) From 1980 to 2003, a reduction of $57 \%$ in formula funds occurred (9). During this same period, competitive grant funding increased and was touted as a replacement for this reduction in funds. However, analysis of the impact of competitive funding versus formula funding indicates that competitive grant funding is less efficient in improving agricultural productivity (9). One reason may be that a higher percentage of competitive grant funding is allocated to overhead costs compared with formula funds. Also, there is an uneven distribution of competitive funds across states because national competitive sources tend to favor national agricultural issues over local or regional problems. Therefore, limited resources are reallocated away from widely dispersed, local agricultural issues to centrally addressed national priorities.

In addition to previous reductions in formula funding, there have been recent reductions in funding for competitive grant programs. In the fiscal years 2011 and 2012 budgets there were reductions in funding for many grant programs that support local and regional priorities - the priorities often addressed by extension plant pathology research. For example, the USDA NIFA Crops at Risk (CAR) and Risk Avoidance Mitigation (RAMP) programs were eliminated.

Extension programs are supported by several funding sources, including county, state, and federal programs, and by clientele such as commodity groups (16). Ahern et al. (3) reported in 2003 that $49 \%$ of the total funds for extension are derived from the states and $27 \%$ from federal sources. The state funds that support extension are also now under great duress. Projected losses will further erode extension programming, placing an increased emphasis on the development of programs with the potential for revenue generation rather than responsiveness to emerging issues.

During the period from 1977 to 1992, the number of full-time equivalents (FTEs) in overall extension programs in agriculture and natural resources experienced a small increase (3). In more recent analyses between 1997 and 2007, a small reduction in the number of extension plant pathologists was observed in one survey (7), and a slight increase in another (10). Some of the increase observed between 1997 and 2007 was due to the establishment of the National Plant Diagnostic Network (NPDN) in 2002 (10). However, in 2011 the U.S. House of Representatives 
Agriculture Appropriations committee had zeroed out funding for NPDN. Funding was subsequently restored at approximately $60 \%$ of previous levels with the added provision that overhead costs of $10 \%$ were allowed, further reducing funding for programs. NPDN is critical to timely diagnosis of disease and maintaining collaborations among states. It is especially important to local and regional plant industries. Reduction of federal funding for NPDN will have serious economic consequences for U.S. agriculture.

At five of our seven institutions, in the period from 2007 to 2012, extension plant pathology has seen a sharp reduction in number of faculty and in FTEs (Table 1). Overall, our institutions lost approximately $18 \%$ of our FTEs in extension plant pathology. In addition to losses in FTEs, there has been a trend toward refilling positions with faculty that also have responsibilities in areas other than plant pathology, diluting the overall plant pathology effort. These losses threaten the ability of land-grant institutions to deliver applied research, diagnostics, and education, and place U.S. agriculture at a competitive disadvantage.

As extension plant pathologists have become more specialized, they have developed regionally or nationally recognized research programs, especially those extension plant pathologists on the tenure track. Such research programs are expected to support extension activities by securing competitive grants that are highly competitive on the national level. Fortunately, some large grant programs require extension components; however, in some instances, when awarded, extension components are treated as "add-ons", with no real plans or goals outlined for extending knowledge to clientele. These extension components often receive a very small proportion of overall funding, which fails to support basic extension needs such as maintenance of equipment used on research stations, the upkeep of vehicles necessary to collaborate with clientele on farms, the hiring of staff who are capable of interfacing with the public, support for graduate students or postdoctoral positions, and managing a multi-faceted extension program.

\section{RECOMMENDATIONS}

The combined shifts toward greater specialization and the increase in split extension appointments with larger research components have improved the ability of extension plant pathologists to compete for grant funding. This positive change has occurred as a greater percentage of extension program funding comes from competitive grants rather than formula funds. However, the longterm success of extension plant pathology programs will depend on maintaining a baseline level of formula funds and on the availability of grant programs that address local and regional needs that recognize (and fund) excellence in outreach. Four specific funding needs are outlined below.

1. Maintain a level of formula funds to provide basic, longterm support for extension plant pathology personnel for all states. The case scenarios at the beginning of this article present only a small glimpse into the diversity of extension plant pathology programs. Variation in commodities, climate, proximity to large urban areas, agricultural imports of like commodities, and local agricultural practices are some of the reasons that plant disease issues are so variable throughout the United States. Even when extension plant pathology positions are shared between states, adequate plant pathology staffing is critical to the economic competitiveness of each state's agricultural enterprises. Critical staffing includes diagnostic extension plant pathologists supported by the NPDN, to provide rapid response to plant disease issues.

2. Increase readily available funding to address plant pathology issues that emerge within a growing season or production cycle. As program funding moves increasingly to grants and away from formula funds, extension plant pathologists find themselves challenged to maintain the flexibility to meet their proactive and reactive roles. The Kellogg Commission in 2001 recommended that "academic leaders secure stable funding to support engagement, through reallocation of existing funds or establishment of a new federal-state-local-private matching fund" (18). However, most land-grant University systems have not achieved this goal. Extension plant pathologists must respond to emerging issues, and to plant disease problems that develop rapidly and have the potential to cause economic losses. This need requires extension plant pathologists to maintain the flexibility and resources to respond quickly to disease issues that are not included in an existing grant-funded project.

Regional Integrated Pest Management (IPM) centers have developed specific grant programs that target critical and emerging issues. These competitive "mini" or "special issues" grants, typically between $\$ 5,000$ and $\$ 10,000$, are available to quickly address a pest problem that arises during the off-cycle of regular funding. "Mini" or "special issues" grants have funded numerous locally important programs. Examples of local plant pathology issues that have been addressed are: disease management in organic apples in Iowa, fungicide resistance management guides for vegetable crops in the mid-Atlantic region, risk assessment of viruses of blueberry in Michigan, and Thousand Cankers Disease in the Western region (http://projects.ipm.gov). Funding for these programs should be increased to allow extension plant pathologists to address high priority local or regional emerging needs.

3. Maintain and enhance grant programs with funding to address regional and state issues. Regional grant programs that focus on local issues such as the regional IPM and regional Sustainable Agriculture Research and Extension (SARE) programs have funded excellent extension-related research projects. The adaptive research they fund is often proactive, such as the development of new methods of disease diagnosis and disease management. These regional grant programs have funded projects as diverse as the development of web-based resources to train scouts in disease identification on onion in New York to the development of region-specific practices for Cucurbit yellow

TABLE 1. Extension plant pathology personnel at seven land-grant institutions across the United States

\begin{tabular}{|c|c|c|c|c|c|}
\hline \multirow[b]{2}{*}{ Location of extension program } & \multicolumn{2}{|c|}{2007} & \multicolumn{2}{|c|}{2011} & \multirow{2}{*}{$\frac{\text { Change }(\%)}{\text { FTE }}$} \\
\hline & FTE $^{\mathrm{a}}$ & No. & FTE & No. & \\
\hline University of Maryland & 5.65 & 7 & $3.65^{b}$ & 5 & -35 \\
\hline University of Wisconsin & 2.79 & 5 & 3.66 & 5 & +31 \\
\hline South Dakota State University & 1.5 & 2 & 0.75 & 1 & $-50^{\mathrm{c}}$ \\
\hline University of California & $19.02^{\mathrm{d}}$ & 72 & 15.40 & 66 & -19 \\
\hline The Pennsylvania State University & 4.22 & 9 & 2.93 & 7 & -31 \\
\hline North Carolina State University & 7.11 & 12 & 4.54 & 9 & -36 \\
\hline University of Florida & 6.1 & 11 & 7.05 & 13 & +13.48 \\
\hline
\end{tabular}

${ }^{a}$ Full-time equivalent (FTE) is the sum of the percentage of all extension plant pathology faculty appointments that are dedicated to extension.

b One 1.0 FTE appointment that was lost is projected to be rehired as a shared appointment with another state.

c A portion of these FTE are projected to be rehired as field specialists with multiple responsibilities (both crop production and plant pathology)

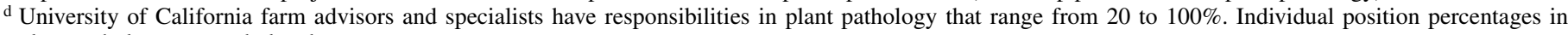
plant pathology were tabulated. 
stunting disorder virus in Arizona (http://projects.ipm.gov). In addition to applied research grants, Partnership grants are awarded by the regional IPM and SARE programs, which emphasize extension activity (http://www.sare.org/Project-Reports). These grant programs excel at getting input from agricultural producers and industries both through establishing working groups to set priorities and by including industry representatives, as appropriate, on grant review panels. Funding for regional IPM and regional SARE and other similar programs should be strengthened and expanded to support regional research and extension projects. Funding levels for individual projects should be adequate to hire graduate students or postdoctoral scientists.

4. Ensure that extension components of large grants support real client linkages and extension programs that are focused on support of growers. Don't support "add-ons" as valid extension components. To maintain extension flexibility and public value, we believe that the National Institute of Food and Agriculture must strengthen the requirements for extension participation in grants and increase funding to support extension components of grants. These dollars must be accompanied by an understanding of the importance of engagement at the local and regional level (in addition to the national level). There should be clear recognition that giving a talk or two, and developing a web page, if not within the framework of an ongoing extension program, or the development of a comprehensive program will not serve as valid extension components of a grant. It is important to include extension plant pathologists (with experience and appreciation of the true costs of excellent extension programs - in the absence of formula funds) on grant review panels. Funding the true cost of extension is necessary to compensate for the reduction in resources from the decrease in formula funds.

\section{CONCLUSIONS}

Increasing demand for high-quality, unbiased extension plant pathology information coupled with a continued reduction in local, state, and federal funds is unsustainable. State and federal funding reductions for extension threaten the ability of extension plant pathologists to maintain preparedness, to conduct research, and to provide outreach. To offset these losses grant funding must address local and regional plant pathology issues. Grant funding should support highly trained personnel and lab facilities in order to maintain extension plant pathology responsiveness, provide for the training of the next generation of extension plant pathologists and fund the cost of project impact assessment that often falls outside the grant timeline and must be conducted by extension faculty.

Maintaining strong support for the cohort of scientists who continue to serve the public interest depends on strong funding for diagnostic services, translational research, recognition of regional and state disease issues, grant funding to support problems that need near-term solutions, and funding for educational efforts to maintain productivity in plant production industries.

\section{LITERATURE CITED}

1. Adaskaveg, J. E., Forster, H., Gubler, W. D., Teviotdale, B. L., and Thompson, D. F. 2005. Reduced risk fungicides help manage brown rot and other fungal diseases of stone fruit. Calif. Agric. 59:2.

2. Agunda, R., and Igodan, C. 2007. Organic farmers' need for and attitude towards extension. Journal of Extension (online) 45(6FEA6) http:// www.joe.org/joe/2007december/a6.php.

3. Ahern, M., Lee, J., and Bottom, J. 2003. Regional trends in extension resources. USDA, ERS. Agric. Inform. Rep. No. 791.

4. Anonymous. 2009. Serious scab problems in southern wheat states. Salem-News.com (online) http://www.salem-news.com/articles/june052009/ wheat_scabs_6-4-09.php.

5. Barber, D. (2009, August 9). You say tomato: I say agricultural disaster. New York Times. Retrieved April 26, 2011 from http://www. nytimes.com/2009/08/09/opinion/09barber.html.

6. Fischer, K. 2009. Economy forces land-grant universities to reshape extension work. The Chronicle of Higher Education. Retrieved April 27, 2011 from http://www.chronicle.com/article/Economy-Forces-Land-Grant/ 49456/.

7. Gadoury, D. M., Andrews, J., Baumgartner, K., Burr, T. J., Kennelly, M. M., Lichens-Park, A., MacDonald, J., Savary, S., Scherm, H., Tally, A., Wang, G.-L. 2009. Disciplinary, institutional, funding and demographic trends in plant pathology: What does the future hold for the profession? Plant Dis. 93:1228-1237.

8. Gubler, W. D., Rademacher, M. R., and Vasquez, S. J., and Thomas, C. S 1999. Control of powdery mildew using the UC Davis powdery mildew risk index. APSnet Feature. doi: 10.1094/APSnetFeature-1999-0199. http:// www.apsnet.org/publications/apsnetfeatures/Pages/UCDavisRisk.aspx.

9. Huffman, W. E., and Evenson, R. E. 2006. Do formula or competitive grant funds have greater impacts on state agricultural productivity? Am. J. Agric. Econ. 84:783-798.

10. Jacobson, B. J., Burrows, M. E., and Ong, K. L. 2008. Extension plant pathology: Bringing our science to the public, a century of service. APSnet Feature. doi: 10.1094/APSnetFeature-2008-0508.

11. Johnson, D. A., Cummings, T. F., and Hamm, P. B. 2000. Cost of fungicides used to manage potato late blight in the Columbia Basin: 1996 to 1998 . Plant Dis. 84:399-402.

12. Moskin, J. 2009. Outbreak of fungus threatens tomato crop. New York Times. Retrieved April 28, 2011 from http://www.nytimes.com/2009/07/ 18/nyregion/18tomatoes.html.

13. Osborne, L. 2009. Corn ear molds. South Dakota Cooperative Extension Service. Blights and Insights Vol. 1, Issue 8b. Nov. 3, 2009 (online) http://www.sdstate.edu/ps/plant-path/upload/BnI_2009_No_8b.pdf.

14. Osborne, L., and Tande, C. 2009. Corn ear molds: The saga continues... South Dakota Cooperative Extension Service. Blights and Insights Vol. 1, Issue 9, November 15, 2009 (online) http://www.sdstate.edu/ps/plantpath/upload/BnI_2009_No_9.pdf.

15. Ragsdale, N. N. 2000. The impact of the Food Quality Protection Act on the future of plant disease management. Annu. Rev. Phytopathol. 38:577596. doi: 10.1146/annurev.phyto.38.1.577.

16. Sherf, A. F. 1973. The development and future of extension plant pathology in the United States. Annu. Rev. Phytopathol. 11:4875-512.

17. Shtienberg, D., and Fry, W. E. 1990. Field and computer simulation evaluation of spray-scheduling methods for control of early and late blight of potato. Phytopathology 80:772-777.

18. Spanier, G., Spikes, D. R., Byrne, J. V., Magrath, C. P., Barker, J. F., Bernstine, D. O., Bowen, R. M., Coor, L. F., Hoff, P. S., Jischke, M. C., Kirwan, W. E., Lawrence, F. L., McDonald, J., McPherson, M. P., Moeser, J., O’Brien, G. M. S. L., Payton, B. F., Ramaley, J. A., Reynolds, W. A., Risser, P., Smith, S. H., Stukel, J. J., Vanderhoef, L., Ward, D., Young, C. E., and Yudof, M. (2001, January). Returning to our roots: Executive summaries of the reports of the Kellogg Commission on the future of state and land-grant universities. Retrieved April 27, 2011 from http://www.aplu.org/NetCommunity/Document.Doc?id=187.

19. U.S. Wheat and Barley Scab Initiative. 2009. Fusarium Focus. Scabs '09 Impact: Benign in some areas troublesome in others. (online) fus-focus_10-09_newsletter.pdf archived at http://www.scabusa.org/pdfs/.

20. West, B. C., Drake, D., and Londo, A. 2009. Extension: A modern-day Pony Express? Journal of Extension (online) 47 (2com1) http:// www.joe.org/joe/2009april/comm1.php. 